\title{
Optimasi Proses Fermentasi Semi Padat Onggok Singkong Menggunakan Metode Response Surface Methodology (RSM)
}

\section{Optimization of The Semi-Solid Fermentation of Cassava Pulp Using Response Surface Methodology (RSM)}

\author{
Beni Hidayat $^{1,2^{*}}$, Udin Hasanudin ${ }^{3}$, M. Muslihudin ${ }^{1}$, Syamsu Akmal ${ }^{1}$, Siti \\ Nurdjanah $^{3}$, Neti Yuliana ${ }^{3}$
}

${ }^{1)}$ Jurusan Teknologi Pertanian, Politeknik Negeri Lampung

${ }^{2)}$ Program Studi Doktor Ilmu Pertanian, Universitas Lampung

3) Jurusan Teknologi Hasil Pertanian, Fakultas Pertanian, Universitas Lampung

"E-mail: beni_lpg@polinela.ac.id

\begin{abstract}
The application of semi-solid fermentation has been able to increase the potential for using cassava pulp, an underused biomass from starch processing (tapioca), as foodstuffs which are reflected in an increase in protein content up to $7.07 \%$ and a decrease in cyanide content to less than $10 \mathrm{mg} / \mathrm{kg}(8.78 \mathrm{mg} / \mathrm{kg})$. Further process optimization is required if the cassava pulp fermentation process is to be carried out on an industrial scale. This research was aimed to obtain the optimal fermentation process parameters to produce cassava pulp flour with optimal characteristics as foodstuffs. Optimization of the fermentation process was carried out using the Response Surface Methodology (RSM) with the Central Composite Design model. There were three optimized factors, namely the concentration of $S$. cerevisiae (1\%-3\%), ammonium sulfate concentration (1\%-2\%), and fermentation time (72-120 hours). The determination of the upper and lower limits was based on preliminary research. The optimal characteristics of fermented cassava pulp flour is obtained in the process parameters: starter concentration 1.67\%, ammonium sulphate concentration $1.00 \%$, and fermentation time 77.65 hours. The optimal process parameters will produce fermented cassava pulp flour with a protein content of $6.17 \%$, cyanide content of $8.64 \mathrm{mg} / \mathrm{kg}$, and an odour score of 4.93 (maximum score of 5 , like very much) which is very potential to be used as foodstuffs.
\end{abstract}

Keywords: cassava pulp, foodstuffs, response surface methodology, semi-solid fermentation

Disubmit : 28 Maret 2021; Diterima: 20 April 2021; Disetujui : 30 Agustus 2021

\section{PENDAHULUAN}

Onggok singkong (ubi kayu) merupakan produk samping utama industri tapioka yang jumlahnya dapat mencapai 33,25\% dari total bahan baku ubi kayu (Suroso, 2011). Potensi onggok untuk dijadikan bahan pangan terutama didasarkan pada tingginya kadar pati dan serat pangan, masing-masing sebesar 55,5\% bk dan 35,2\% bk (basis kering) (Chaikaew et al., 2012). Kendala yang dihadapi jika onggok akan dijadikan bahan pangan adalah tingginya kadar sianida mengingat sebagian besar ubi kayu yang digunakan sebagai bahan baku industri tapioka adalah ubi kayu racun (tinggi sianida). Sianida pada ubi kayu berupa komponen glikosida sianogenik (linamarin dan lotaustralin) yang jika terhidrolisis akan melepaskan asam hidrosianat, senyawa yang bersifat toksik bagi manusia (Etsuyankpa et al., 2015). Selain kandungan sianida, kendala 
lain yang perlu diatasi jika onggok akan dijadikan bahan pangan adalah rendahnya kandungan protein (Ubalua, 2007).

Proses fermentasi merupakan proses yang paling potensial diterapkan untuk meningkatkan kadar protein dan menurunkan kadar sianida onggok. Berdasarkan karakteristik onggok yang memiliki kadar air tinggi maka proses fermentasi yang dilakukan dapat berupa proses fermentasi semi padat. Menurut Ezekiel dan Aworh (2013), dibandingkan dengan metode fermentasi lainnya, fermentasi semi padat merupakan metode yang paling sesuai digunakan untuk meningkatkan kadar protein onggok karena relatif murah dan efisien. Adapun menurut (Oboh dan Akindahunsi, 2003), pada fermentasi semi padat menggunakan bahan baku ubi kayu dan hasil sampingnya, Saccharomyces cerevisiae merupakan mikroba yang paling potensial digunakan. (Hidayat et al., 2019) melaporkan bahwa fermentasi semi padat onggok singkong menggunakan S. cerevisiae akan meningkatkan kadar protein menjadi 7,07\% dan mengurangi kadar sianida hingga 8,78 $\mathrm{mg} / \mathrm{kg}$.

Dalam rangka penerapan proses fermentasi semi padat onggok pada skala industri, diperlukan upaya optimasi parameter-parameter proses yang akan menentukan karakteristik onggok fermentasi yang dihasilkan. Menurut (Hidayat et al., 2019) dan (Hidayat, Hasanudin, Muslihudin, et al., 2020), parameter proses yang sangat berpengaruh pada proses fermentasi semi padat onggok adalah jenis dan konsentrasi starter $S$. cerevisiae, jenis dan konsentrasi nutrisi amonium sulfat, serta lama fermentasi.

Salah satu metode yang saat ini banyak digunakan untuk optimasi parameter proses adalah metode Response Surface Methodology (RSM). Metode RSM antara lain telah digunakan untuk optimasi karakteristik tepung komposit berbahan dasar millet mutiara (Awolu, 2017), optimasi karakteristik tepung komposit berbahan dasar tepung onggok terfermentasi (Hidayat et al., 2020), optimasi penurunan kadar sianida pada daun ubi kayu (Hawashi et al., 2019). Penelitian ini bertujuan untuk mendapatkan parameter proses fermentasi optimal (konsentrasi starter, konsentrasi amonium sulfat, dan lama fermentasi) untuk menghasilkan tepung onggok terfermentasi dengan karakteristik optimal sebagai bahan pangan menggunakan metode RSM.

\section{METODE PENELITIAN}

Bahan utama yang digunakan adalah ubi kayu var. Kasetsart yang diperoleh dari petani ubi kayu di Desa Margomulyo, Kecamatan Jati Agung, Kabupaten Lampung Selatan. Saccharomyces cerevisiae dalam bentuk bubuk produksi SIL France merk "fermipan" diperoleh dari sebuah toko di Bandar Lampung. Bahan kimia yang digunakan adalah pati (GR, Merck), maltosa (Sigma M5885), asam dinitrosalisilat (DNS, Sigma D-0550), glukosa (Sigma G8270), enzim termamyl ( $\alpha$-amylase, Sigma A-4862), enzim pepsin (Sigma P7000), enzim amiloglukosidase (Sigma A-9913), enzim pankreatin (Sigma P-1750) diperoleh dari PT Elo Karsa, dan amonium sulfat food grade yang dibeli dari Tokopedia (toko online).

Penelitian dilaksanakan di Laboratorium Teknologi Pangan Politeknik Negeri Lampung pada bulan Februari sampai Juni 2020. Perancangan parameter proses dilakukan menggunakan metode Response Surface Methodology (RSM) program Design-Expert versi 7.0. Terdapat tiga faktor yang dioptimasi yaitu konsentrasi Saccharomyces cerevisiae (1\%-3\%), konsentrasi amonium sulfat (1\%-2\%), dan lama fermentasi (72-120 jam). Penentuan batas atas dan batas bawah didasarkan pada penelitian pendahuluan. Penentuan komposisi formulasi dilakukan dengan metode Central Composite Design (CCD) sehingga diperoleh 19 kombinasi parameter proses (Tabel 1).

Penyiapan onggok segar. Penyiapan onggok segar diawali dengan tahapan sortasi ubi kayu, pengupasan dengan metode abrasi (kulit bagian dalam tidak dikupas), penambahan air dengan volume sebanyak 20 kali berat ubi kayu, dan pengepresan hingga air pengepresan berwarna jernih. Onggok yang diperoleh kemudian direndam selama \pm 4 jam sambil diaduk sesekali dan dipress kembali untuk memisahkan airnya. Penyiapan onggok segar. Penyiapan onggok segar diawali dengan tahapan sortasi ubi kayu, pengupasan dengan metode abrasi (kulit bagian dalam tidak dikupas), penambahan air dengan volume sebanyak 20 kali berat ubi kayu, dan pengepresan hingga air pengepresan berwarna jernih. Onggok yang 
diperoleh kemudian direndam selama \pm 4 jam sambil diaduk sesekali dan dipress kembali untuk memisahkan airnya.

Tabel 1. Susunan desain parameter proses fermentasi semi padat onggok menggunakan metode Central Composite Design (CCD)

\begin{tabular}{cccc}
\hline Run & $\begin{array}{c}\text { Konsentrasi starter } \\
(\%)\end{array}$ & $\begin{array}{c}\text { Konsentrasi ammonium } \\
\text { sulfat }(\%)\end{array}$ & $\begin{array}{c}\text { Lama fermentasi } \\
(\text { jam })\end{array}$ \\
\hline 1 & 2,00 & 0,66 & 96,00 \\
2 & 2,00 & 1,50 & 96,00 \\
3 & 0,32 & 1,50 & 96,00 \\
4 & 1,00 & 2,00 & 120,00 \\
5 & 2,00 & 1,50 & 96,00 \\
6 & 3,00 & 2,00 & 72,00 \\
7 & 1,00 & 1,00 & 72,00 \\
8 & 3,00 & 1,00 & 120,00 \\
9 & 3,00 & 2,00 & 120,00 \\
10 & 1,00 & 2,00 & 72,00 \\
11 & 1,00 & 1,00 & 120,00 \\
12 & 2,00 & 1,50 & 96,00 \\
13 & 3,00 & 1,00 & 72,00 \\
14 & 3,68 & 1,50 & 96,00 \\
15 & 2,00 & 1,50 & 55,64 \\
16 & 2,00 & 1,50 & 96,00 \\
17 & 2,00 & 2,34 & 96,00 \\
18 & 2,00 & 1,50 & 136,36 \\
19 & 2,00 & 1,50 & 96,00 \\
\hline
\end{tabular}

Proses fermentasi onggok. Starter Saccharomyces cerevisiae dalam bentuk bubuk (konsentrasi sesuai perlakuan) dan amonium sulfat (konsentrasi sesuai perlakuan), dicampur merata dengan onggok. Selanjutnya onggok dimasukkan ke dalam wadah toples plastik dengan penutup berlubang. Fermentasi dilakukan pada suhu kamar dengan lama fermentasi sesuai perlakuan.

Proses pengeringan dan penggilingan onggok. Pengeringan onggok hasil fermentasi dilakukan menggunakan cabinet dryer pada suhu $50^{\circ} \mathrm{C}$ selama 5-6 jam dilanjutkan dengan penggilingan hingga diperoleh tepung ubi kayu 80 mesh.

Pemilihan parameter proses optimal. Respon yang diamati untuk seluruh perlakuan (19 run) adalah kadar protein (\%), kadar pati (\%), kadar sianida $(\mathrm{mg} / \mathrm{kg})$, kadar serat pangan (\%), dan skor aroma. Kadar protein ditentukan menurut metode (AOAC Internasional, 1999) dalam bentuk protein kasar ( $\mathrm{N}$ x 6,25); kadar pati diukur dengan metode spektrofotometri (Goni et al, 1997) dengan sedikit modifikasi menggunakan DNS (Hidayat et al, 2018); kadar sianida ditentukan dengan menggunakan titrasi basa) (Onyesom et al, 2008); serat pangan ditentukan dengan metode enzimatik menggunakan enzim termamyl, pepsin, dan pankreatin (Asp et al., 1983), dan skor aroma dievaluasi dengan uji sensorik (Soekarto, 1985). Parameter proses yang optimal dipilih dengan metode numerik berdasarkan kriteria konsentrasi starter (\%) minimum, konsentrasi amonium sulfat (\%) minimum, dan lama fermentasi maksimum. Adapun kriteria respon berdasarkan kadar protein maksimum $(\%), \mathrm{HCN}$ minimum $(\mathrm{mg} / \mathrm{kg})$, dan skor aroma maksimum. 


\section{HASIL DAN PEMBAHASAN}

Respon komposisi kimia dan sensoris tepung onggok terfermentasi meliputi kadar protein (\%), kadar pati (\%), kadar sianida (mg/kg), serat pangan (\%), dan skor aroma disajikan pada Tabel 2. Pada Tabel 2, terlihat bahwa kadar protein tepung onggok terfermentasi bervarasi dari terendah $3,10 \%$ pada perlakuan konsentrasi starter 0,32\%, konsentrasi amonium sulfat 1,50\%, dan lama fermentasi 96 jam. Adapun kadar protein tertinggi $(8,08 \%)$ diperoleh pada perlakuan konsentrasi starter 2,00\%, konsentrasi ammonium sulfat $1,50 \%$, dan lama fermentasi $96 \mathrm{jam}$. Kadar sianida terendah $(6,4 \mathrm{mg} / \mathrm{kg})$ diperoleh pada perlakuan konsentrasi starter 3,00\%, konsentrasi ammonium sulfat 2,00\%, dan lama fermentasi 72 jam. Sedangkan kadar sianida tertinggi $(25,9 \mathrm{mg} / \mathrm{kg})$ diperoleh pada perlakuan konsentrasi starter $0,32 \%$, konsentrasi ammonium sulfat $1,50 \%$, dan lama fermentasi 96 jam.

Tabel 2. Respon komposisi kimia dan sensoris tepung onggok terfermentasi

\begin{tabular}{ccccccccc}
\hline Run & $\begin{array}{c}\text { Konsentra- } \\
\text { si starter } \\
(\%)\end{array}$ & $\begin{array}{c}\text { Konsentrasi } \\
\text { amonium } \\
\text { sulfat }(\%)\end{array}$ & $\begin{array}{c}\text { Lama } \\
\text { fermenta- } \\
\text { si (jam) }\end{array}$ & $\begin{array}{c}\text { Kadar } \\
\text { protein } \\
(\%)\end{array}$ & $\begin{array}{c}\text { Kadar } \\
\text { Pati }(\%)\end{array}$ & $\begin{array}{c}\text { Kadar } \\
\text { sianida } \\
(\mathrm{mg} / \mathrm{kg})\end{array}$ & $\begin{array}{c}\text { Kadar serat } \\
\text { pangan } \\
(\%)\end{array}$ & $\begin{array}{c}\text { Skor } \\
\text { aroma }\end{array}$ \\
\hline 1 & 2,00 & 0,66 & 96,00 & 5,61 & 57,70 & 10,8 & 23,77 & 4,40 \\
2 & 2,00 & 1,50 & 96,00 & 8,08 & 57,84 & 8,6 & 16,39 & 3,88 \\
3 & 0,32 & 1,50 & 96,00 & 3,10 & 61,41 & 25,9 & 31,20 & 3,88 \\
4 & 1,00 & 2,00 & 120,00 & 4,52 & 60,86 & 18,3 & 26,10 & 3,04 \\
5 & 2,00 & 1,50 & 96,00 & 6,87 & 55,82 & 8,6 & 19,86 & 3,72 \\
6 & 3.00 & 2,00 & 72,00 & 6,50 & 56,14 & 6,4 & 21,45 & 2,92 \\
7 & 1,00 & 1,00 & 72,00 & 4,87 & 59,10 & 8,9 & 24,82 & 4,56 \\
8 & 3,00 & 1,00 & 120,00 & 5,99 & 57,20 & 8,9 & 22,10 & 3,72 \\
9 & 3,00 & 2,00 & 120,00 & 6,46 & 56,30 & 11,1 & 22,04 & 2,96 \\
10 & 1,00 & 2,00 & 72,00 & 4,58 & 60,10 & 20,6 & 24,84 & 2,84 \\
11 & 1,00 & 1,00 & 120,00 & 3,58 & 61,10 & 19,8 & 28,21 & 4,68 \\
12 & 2,00 & 1,50 & 96,00 & 6,91 & 55,45 & 10,6 & 19,42 & 4,04 \\
13 & 3,00 & 1,00 & 72,00 & 6,36 & 56,77 & 10,7 & 22,75 & 4,48 \\
14 & 3,68 & 1,50 & 96,00 & 5,92 & 57,36 & 8,8 & 22,98 & 3,76 \\
15 & 2,00 & 1,50 & 55,64 & 5,81 & 57,39 & 8,6 & 23,60 & 3,84 \\
16 & 2,00 & 1,50 & 96,00 & 7,10 & 55,42 & 10,6 & 19,14 & 3,96 \\
17 & 2,00 & 2,34 & 96,00 & 7,38 & 55,04 & 6,4 & 17,30 & 2,12 \\
18 & 2,00 & 1,50 & 136,36 & 5,03 & 58,60 & 19,7 & 24,36 & 3,80 \\
19 & 2,00 & 1,50 & 96,00 & 6,61 & 55,98 & 8,9 & 20,70 & 3,92 \\
\hline
\end{tabular}

Deskripsi skor aroma

$1=$ sangat tidak suka $\quad 2=$ tidak suka $3=$ agak suka $\quad 4=$ suka

5 = sangat suka

Pada metode Response Surface Methodology, analisis lebih lanjut dilakukan jika respon hasil pengamatan berupa model kuadratik yang menunjukkan bahwa terdapat titik optimal pengamatan. Hasil analisis ANOVA untuk model kuadratik Response Surface Methodology disajikan pada Tabel 3. Hasil analisis (Tabel 3), menunjukkan bahwa parameter konsentrasi starter, konsentrasi amonium sulfat, dan lama fermentasi berpengaruh nyata $(\mathrm{P}<0,05)$ untuk semua variabel respon yaitu kadar protein $(\%)$, kadar pati $(\%)$, kadar sianida $(\mathrm{mg} / \mathrm{kg})$, kadar serat pangan $(\%)$, dan skor aroma. 
Tabel 3. Analisis ANOVA untuk model kuadratik Response Surface Methodology

\begin{tabular}{lccccl}
\hline Respon variabel & Nilai F & Nilai P. & Nilai R & Adj. Nilai R & Signifikansi \\
\hline Kadar protein (\%) & 15,00 & 0,0002 & 0,9375 & 0,8750 & Signifikan \\
Kadar pati (\%) & 8,57 & 0,0019 & 0,8956 & 0,7911 & Signifikan \\
Kadar sianida (mg/kg) & 5,45 & 0,0094 & 0,8449 & 0,6899 & Signifikan \\
Kadar serat pangan (\%) & 10,39 & 0,0009 & 0,9122 & 0,8244 & Signifikan \\
Skor aroma & 12,32 & 0,0015 & 0,9925 & 0,9729 & Signifikan \\
\hline
\end{tabular}

\section{Kadar protein}

Kadar protein tepung onggok terfermentasi bervariasi dari 3,10\% hingga 8,08\% (Tabel 2). Hasil analisis ANOVA menunjukkan bahwa model kuadratik memiliki pengaruh yang nyata $(\mathrm{P}<0.05)$ terhadap kadar protein tepung onggok terfermentasi dengan nilai $\mathrm{R}^{2}$ dan adjusted $\mathrm{R}^{2}$ masing-masing sebesar 0,9375 dan 0,8750 (Tabel 3). Hal ini menunjukkan bahwa terdapat konsentrasi starter optimal, konsentrasi amonium sulfat optimal, dan lama fermentasi optimal yang akan menghasilkan tepung onggok fermentasi dengan kadar protein tinggi. Respon kadar protein tepung onggok terfermentasi terhadap berbagai parameter konsentrasi starter dan konsentrasi amonium sulfat pada lama fermentasi 96 jam, disajikan pada Gambar 1.

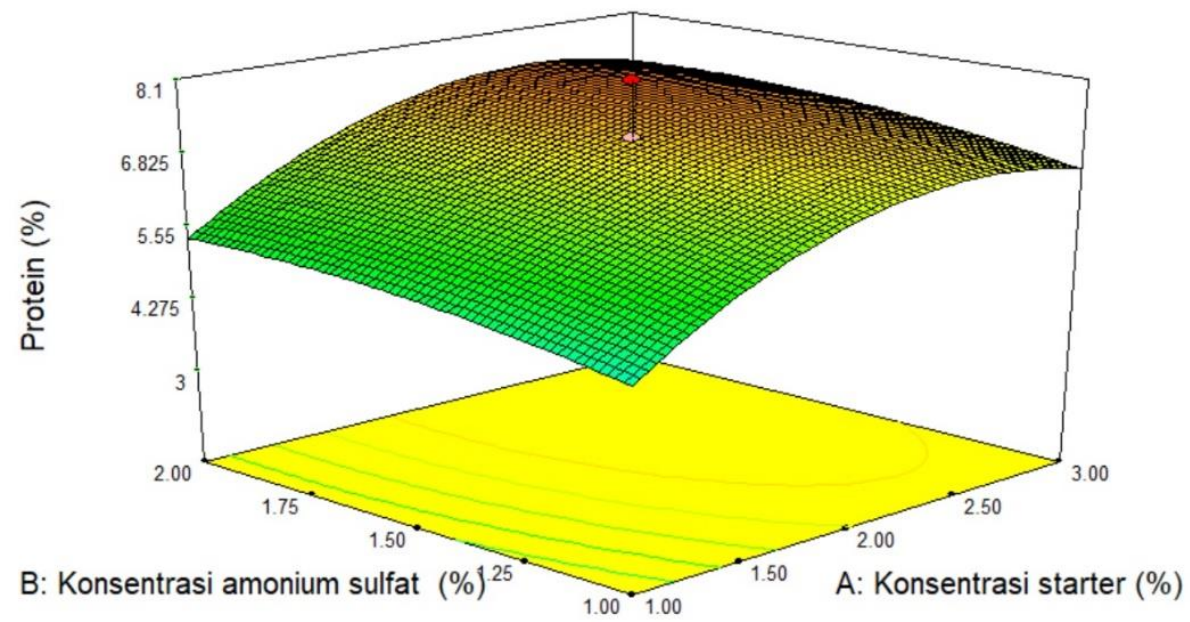

Gambar 1. Respon kadar protein tepung onggok terfermentasi terhadap berbagai parameter konsentrasi starter dan konsentrasi amonium sulfat pada lama fermentasi 96 jam.

Pengaruh parameter proses terhadap kadar protein disajikan dalam bentuk persamaan (1). Persamaan (1) menunjukkan bahwa konsentrasi starter (A) dengan koefisien tertinggi $(+0,92)$ berpengaruh positif tertinggi terhadap kadar protein. Hal ini menunjukkan bahwa konsentrasi starter merupakan parameter proses yang paling berpengaruh terhadap kadar protein tepung onggok terfermentasi. Peningkatan kadar protein selama fermentasi onggok berkaitan erat dengan pembentukan biomassa mikroba (protein sel tunggal) (Oboh and Akindahunsi, 2003); (Kaewwongsa et al., 2010). Semakin tinggi biomassa yang terbentuk maka semakin tinggi kandungan protein tepung onggok terfermentasi.

Protein $(\%)=+7,11+0,92 \mathrm{~A}+0,31 \mathrm{~B}-0,23 \mathrm{C}-5,487 \mathrm{E} .003 \mathrm{AB}+0,12 \mathrm{AC}+0,20 \mathrm{BC}-0,92 \mathrm{~A} 2-0,22 \mathrm{~B} 2-0,60 \mathrm{C} 2$ 


\section{Kadar pati}

Kadar pati tepung onggok terfermentasi bervariasi dari 55,04\% hingga 61,41\% (Tabel 2). Hasil analisis ANOVA menunjukkan bahwa model kuadratik memiliki pengaruh yang nyata $(\mathrm{P}<0,05)$ terhadap kadar pati tepung onggok terfermentasi dengan nilai $\mathrm{R}^{2}$ dan adjusted $\mathrm{R}^{2}$ masing-masing sebesar 0,8956 dan 0,7911 (Tabel 3). Hal ini menunjukkan bahwa terdapat konsentrasi starter optimal, konsentrasi amonium sulfat optimal, dan lama fermentasi optimal yang akan menghasilkan tepung onggok fermentasi dengan kadar pati rendah. Respon kadar pati tepung hasil fermentasi terhadap berbagai parameter konsentrasi starter dan konsentrasi amonium sulfat pada lama fermentasi 96 jam, disajikan pada Gambar 2.

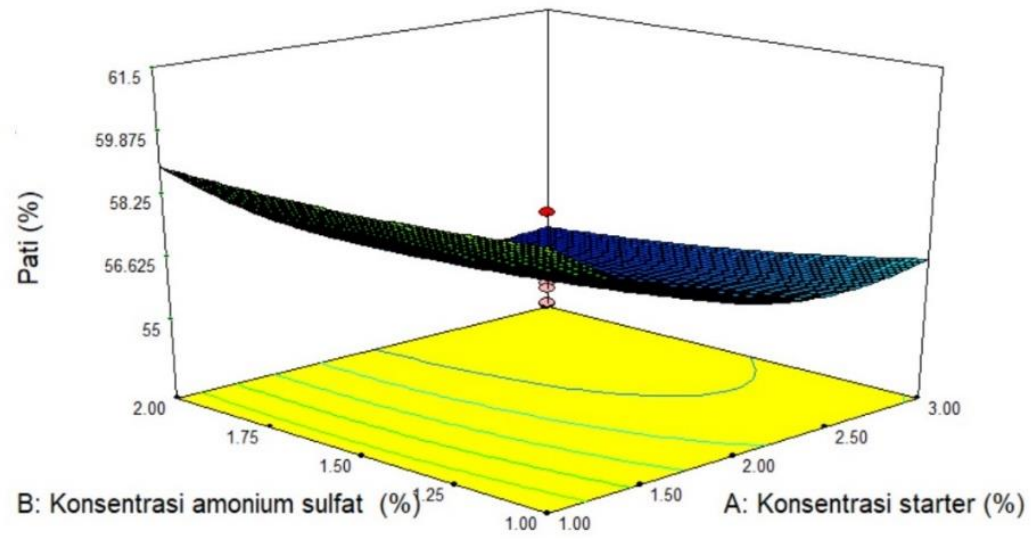

Gambar 2. Respon kadar pati tepung onggok terfermentasi terhadap berbagai parameter konsentrasi starter dan konsentrasi amonium sulfat pada lama fermentasi 96 jam.

Pengaruh parameter proses terhadap kadar pati tepung onggok terfermentasi, disajikan dalam bentuk persamaan (2). Persamaan (2), menunjukkan bahwa konsentrasi starter (A) dengan koefisien tertinggi (1,58) berpengaruh negatif tertinggi terhadap kadar pati. Hal ini menunjukkan bahwa konsentrasi starter merupakan parameter proses yang paling berpengaruh terhadap kadar pati tepung onggok terfermentasi. Semakin tinggi konsentrasi starter maka akan semakin rendah kadar pati tepung onggok yang dihasilkan. Penurunan kadar pati selama fermentasi berkaitan dengan penggunaannya sebagai sumber nutrisi (Hidayat $e t$ al., 2020). Saccharomyces cerevisiae akan menghasilkan enzim amilase yang akan menghidrolisis pati menjadi komponen sederhana dan menggunakannya sebagai sumber nutrisi) (Oboh and Akindahunsi, 2003).

Pati $(\%)=+56,09-1,58 \mathrm{~A}-0,38 \mathrm{~B}+0,40 \mathrm{C}-0,29 \mathrm{AB}-0,27 \mathrm{AC}-0,19 \mathrm{BC}+1,25 \mathrm{~A} 2+0,18 \mathrm{~B} 2+0,76 \mathrm{C} 2(2)$

\section{Kadar sianida}

Kadar sianida tepung onggok terfermentasi bervariasi dari $6,4 \mathrm{mg} / \mathrm{kg}$ hingga $25,9 \mathrm{mg} / \mathrm{kg}$ (Tabel 2). Hasil analisis ANOVA menunjukkan bahwa model kuadratik memiliki pengaruh yang nyata $(\mathrm{P}<0,05)$ terhadap kadar sianida tepung onggok terfermentasi dengan nilai $\mathrm{R}^{2}$ dan nilai adjusted $\mathrm{R}^{2}$ masing-masing sebesar 0,8449 dan 0,6899 (Tabel 3). Hal ini menunjukkan bahwa terdapat konsentrasi starter optimal, konsentrasi amonium sulfat optimal, dan lama fermentasi optimal yang akan menghasilkan tepung onggok fermentasi dengan kadar sianida rendah. Respon kadar sianida tepung onggok terfermentasi terhadap berbagai parameter konsentrasi starter dan konsentrasi amonium sulfat pada lama fermentasi 96 jam, disajikan pada Gambar 3.

Pengaruh parameter proses terhadap kadar sianida tepung onggok terfermentasi disajikan dalam bentuk persamaan (3). Persamaan (3) menunjukkan bahwa konsentrasi starter (A) dengan koefisien tertinggi $(-4,34)$ berpengaruh negatif tertinggi terhadap kadar sianida. Hal ini menunjukkan bahwa konsentrasi starter merupakan parameter proses yang paling berpengaruh terhadap kadar sianida tepung onggok terfermentasi. 
Semakin tinggi konsentrasi starter maka akan semakin rendah kadar sianida tepung onggok yang dihasilkan. Penurunan kandungan sianida selama proses fermentasi sangat terkait dengan degradasi sianida selama proses fermentasi. Sianida pada ubi kayu dijumpai dalam bentuk senyawa cyanogenic glucosides (CNG) yang tersusun dari 96\% linamarin dan 4\% lotaustralin (Lambri et al., 2013). Hidrogen sianida, bentuk dari sianida yang larut air dan mudah menguap, akan terbentuk jika CNG kontak dengan glikosidase dan hidroksilen lyase (saat jaringan rusak) dan terdegradasi menjadi sianohidrin, hidrogen sianida, dan keton)(Iwuoha et al, 2017). Penurunan kadar sianida dari onggok selama fermentasi berkaitan dengan penggunaan CNG melalui degradasi asimilasi dengan melepaskan hidrogen sianida dan amonia (Murugan $e t$ $a l, 2012)$.

Sianida $(\mathrm{ppm})=+9,48-4,34 \mathrm{~A}+0,051 \mathrm{~B}+2,21 \mathrm{C}-1,54 \mathrm{AB}-0,71 \mathrm{AC}-0,84 \mathrm{BC}+2,68 \mathrm{~A} 2-0,41 \mathrm{~B} 2+1,55 \mathrm{C} 2$

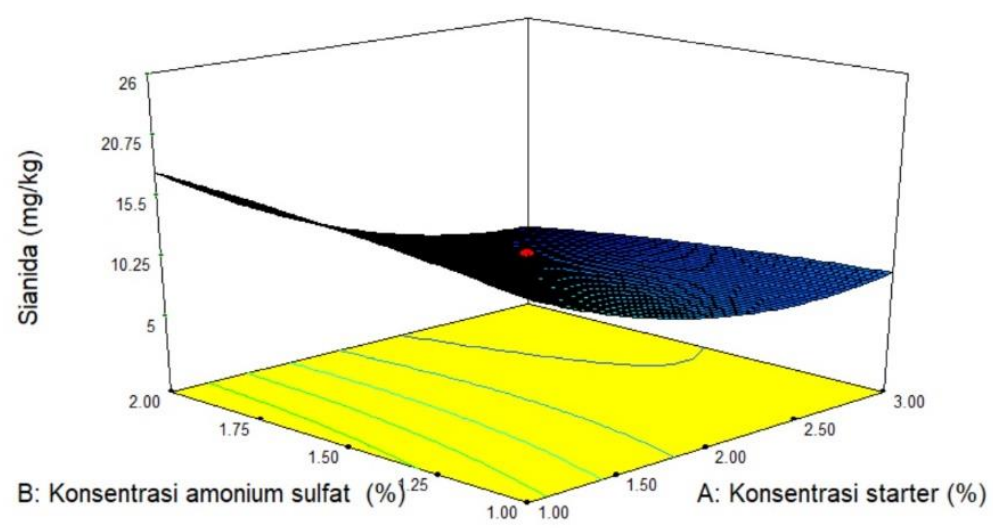

Gambar 3. Respon kadar sianida tepung onggok terfermentasi terhadap berbagai parameter konsentrasi starter dan konsentrasi amonium sulfat pada lama fermentasi 96 jam.

\section{Kadar serat pangan}

Kadar serat pangan tepung onggok terfermentasi bervariasi dari 16,39\% hingga 31,20\% (Tabel 2). Hasil analisis ANOVA menunjukkan bahwa model kuadratik memiliki pengaruh yang nyata $(\mathrm{P}<0,05)$ terhadap kadar serat pangan tepung onggok terfermentasi dengan nilai $\mathrm{R}^{2}$ dan adjusted $\mathrm{R}^{2}$ masing-masing sebesar 0,9122 dan 0,8244 (Tabel 3). Hal ini menunjukkan bahwa terdapat konsentrasi starter optimal, konsentrasi amonium sulfat optimal, dan lama fermentasi optimal yang akan menghasilkan tepung onggok fermentasi dengan kadar serat pangan rendah. Respon kadar serat pangan tepung onggok terfermentasi terhadap berbagai parameter konsentrasi starter dan konsentrasi amonium sulfat pada lama fermentasi 96 jam, disajikan pada Gambar 4.

Pengaruh parameter proses terhadap kadar serat pangan disajikan dalam bentuk persamaan (4). Persamaan (4) menunjukkan bahwa kombinasi konsentrasi starter (A) dengan koefisien tertinggi $(-2,16)$ berpengaruh negatif tertinggi terhadap kadar serat pangan. Berdasarkan persamaan (4), terlihat bahwa konsentrasi starter merupakan parameter yang paling berpengaruh terhadap penurunan kadar serat pangan. Semakin tinggi konsentrasi starter maka akan semakin rendah kadar serat pangan tepung onggok yang dihasilkan. Penurunan kadar serat pangan disebabkan terjadinya degradasi serat pangan selama proses fermentasi. Serat pangan merupakan struktur matriks yang menutupi granula pati pada onggok. Proses fermentasi akan membuka struktur serat pada onggok, sehingga pati menjadi lebih tersedia untuk mikroba (Hidayat et al., 2019). Saccharomyces cerevisiae akan menghasilkan enzim pektinase dan selulase yang mendegradasi serat pangan (Hidayat et al., 2020). 


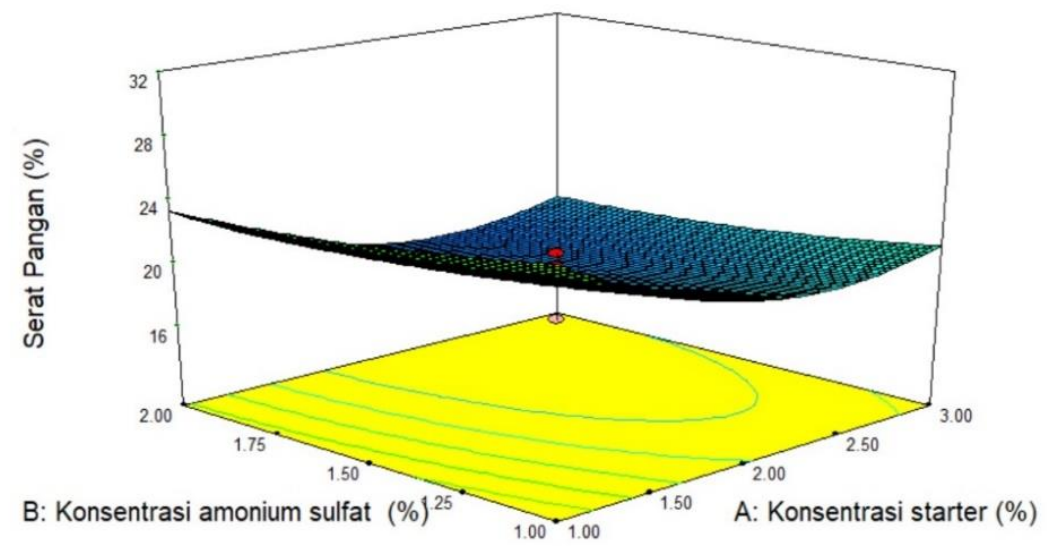

Gambar 4. Respon kadar serat pangan tepung onggok terfermentasi terhadap berbagai parameter konsentrasi starter dan konsentrasi amonium sulfat pada lama fermentasi 96 jam.

\section{Skor Aroma}

Skor aroma tepung onggok terfermentasi bervariasi dari 2,12 hingga 4,56\% (Tabel 2). Hasil analisis ANOVA menunjukkan bahwa model kuadratik memiliki pengaruh yang nyata $(\mathrm{P}<0,05)$ terhadap skor aroma tepung onggok terfermentasi dengan nilai $\mathrm{R}^{2}$ dan adjusted $\mathrm{R}^{2}$ masing-masing sebesar 0,9925 dan 0,9729 (Tabel 3). Hal ini menunjukkan bahwa terdapat konsentrasi starter optimal, konsentrasi amonium sulfat optimal, dan lama fermentasi optimal yang akan menghasilkan tepung onggok fermentasi dengan skor aroma tinggi. Respon skor aroma tepung onggok terfermentasi terhadap berbagai parameter konsentrasi starter dan konsentrasi amonium sulfat pada lama fermentasi 96 jam, disajikan pada Gambar 5.

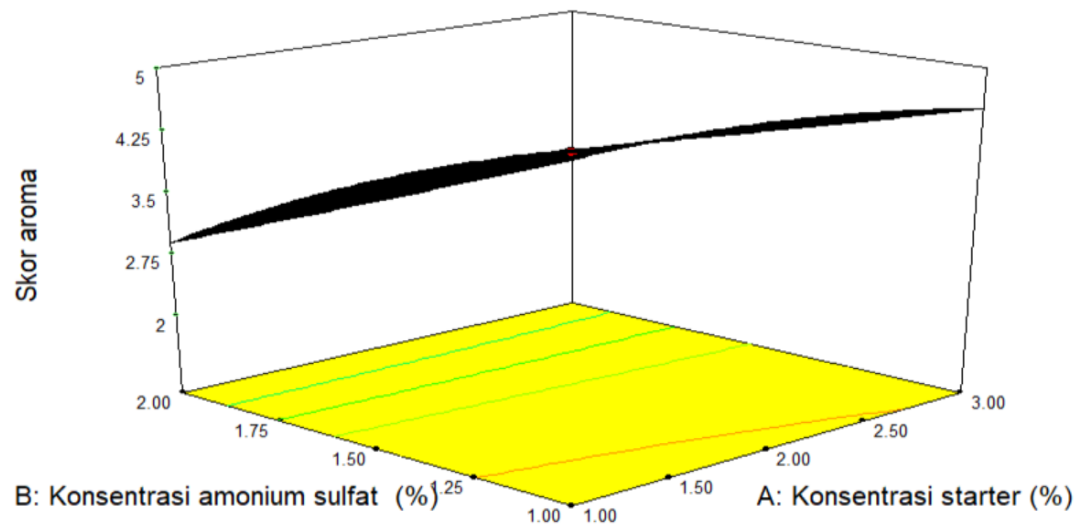

Gambar 5. Respon skor aroma tepung onggok terfermentasi terhadap berbagai parameter konsentrasi starter dan konsentrasi amonium sulfat pada lama fermentasi 96 jam.

Pengaruh parameter proses terhadap skor aroma tepung onggok terfermentasi, disajikan dalam bentuk persamaan (5). Persamaan (5) menunjukkan bahwa konsentrasi amonium sulfat (B) dengan koefisien tertinggi $(-0,70)$ berpengaruh negatif tertinggi terhadap skor aroma. Hal ini menunjukkan bahwa konsentrasi amonium sulfat merupakan parameter proses yang paling berpengaruh terhadap skor aroma tepung onggok terfermentasi.Semakin tinggi konsentrasi amonium sulfat maka akan semakin rendah skor aroma tepung onggok yang dihasilkan. Penurunan skor aroma selama fermentasi berkaitan dengan pembentukan senyawa sulfur akibat degradasi amonium sulfat $\left(\mathrm{NH}_{4}\right)_{2} \mathrm{SO}_{4}$ selama proses fermentasi. Pada proses fermentasi semi padat, amonium sulfat lebih efektif digunakan sebagai sumber nitrogen daripada urea dalam pembentukan biomassa (Ezekiel and Aworh, 2013). 


\section{Pemilihan Parameter Proses Optimal}

Pemilihan parameter proses optimal dilakukan dengan metode numerik berdasarkan kriteria konsentrasi starter minimum (\%), konsentrasi amonium sulfat minimum (\%), dan lama fermentasi minimum (jam); dengan kriteria respon berupa kadar protein maksimal (\%), kadar sianida minimal (mg/kg), dan skor aroma maksimal. Pemilihan kriteria konsentrasi starter minimum didasarkan pada pertimbangan bahwa semakin tinggi konsentrasi starter maka akan semakin besar biaya yang dikeluarkan untuk proses produksi. Pemilihan kriteria konsentrasi amonium sulfat minimum didasarkan pada pertimbangan dan hasil pengujian skor bau bahwa semakin tinggi konsentrasi ammonium sulfat maka skor aroma yang dihasilkan akan semakin rendah. Adapun pemilihan kriteria lama fermentasi minimum didasarkan pada hasil pengujian yang menunjukkan terdapat lama fermentasi optimal untuk menghasilkan tepung onggok fermentasi dengan karakteristik terbaik.

Berdasarkan kriteria tersebut diperoleh 8 parameter proses optimal seperti disajikan pada Tabel 5 . Berdasarkan hasil optimasi pada Tabel 5, jika didasarkan pada kriteria kadar protein maksimal $(6,17 \%)$, maka parameter proses yang paling optimal adalah konsentrasi starter 1,67\%, konsentrasi ammonium sulfat $1,0 \%$, dan lama fermentasi 77,65 jam.

Tabel 5. Hasil optimasi numerik untuk parameter proses pembuatan tepung onggok terfermentasi menggunakan metode Response Surface Methodology

\begin{tabular}{ccccccc}
\hline $\begin{array}{c}\text { Parameter } \\
\text { optimal }\end{array}$ & Starter (\%) & $\begin{array}{c}\text { Amonium } \\
\text { sulfat }(\%)\end{array}$ & $\begin{array}{c}\text { Lama } \\
\text { fermentasi } \\
\text { (jam) }\end{array}$ & Protein $(\%)$ & $\begin{array}{c}\text { Sianida } \\
(\mathrm{mg} / \mathrm{kg})\end{array}$ & Skor aroma \\
\hline 1 & 1,62 & 1,00 & 79,15 & 6,13 & 8,91 & 4,90 \\
2 & 1,61 & 1,00 & 78,65 & 6,11 & 8,91 & 4,91 \\
3 & 1,62 & 1,00 & 80,15 & 6,15 & 8,94 & 4,90 \\
4 & 1,60 & 1,00 & 80,31 & 6,12 & 9,03 & 4,90 \\
5 & 1,58 & 1,00 & 79,74 & 6,08 & 9,10 & 4,90 \\
6 & 1,67 & 1,00 & 77,65 & 6,17 & 8,64 & 4,91 \\
7 & 1,63 & 1,00 & 76,00 & 6,09 & 8,73 & 4,92 \\
8 & 1,71 & 1,00 & 73,51 & 6,14 & 8,36 & 4,93 \\
\hline
\end{tabular}

\section{KESIMPULAN}

Karakteristik optimal tepung onggok terfermentasi diperoleh pada parameter proses: konsentrasi starter $1,67 \%$, konsentrasi amonium sulfat 1,00\%, dan lama fermentasi 77,65 jam. Parameter proses optimal tersebut akan menghasikan tepung onggok terfermentasi dengan kadar protein 6,17\%, kadar sianida 8,64 $\mathrm{mg} / \mathrm{kg}$ dan skor aroma 4,93 (skor maksimal 5; sangat suka) yang sangat potensial digunakan sebagai bahan pangan.

\section{UCAPAN TERIMAKASIH}

Penulis mengucapkan terima kasih kepada Direktorat Riset dan Pengabdian Masyarakat, Kementerian Riset dan Teknologi Republik Indonesia yang telah mendanai penelitian ini melalui skema Riset Penelitian Pengembangan Unggulan Perguruan Tinggi tahun 2020.

\section{DAFTAR PUSTAKA}

AOAC Internasional (1999) 'AOAC Internasional', Association of Official Agricultural Chemists, 16(5).

Asp, N. G. . et al. (1983) 'Rapid enzymatic assay of insoluble and soluble dietary fiber', Journal Agric, 31(3), pp. 476-482. 
Awolu, O. O. (2017) 'Optimization of the functional characteristics, pasting and rheological properties of pearl millet-based composite flour', in Heliyon.

Chaikaew, S. . et al. (2012) 'Application of thermophilic enzymes and water jet system to cassava pulp', Bioresour Technol, 126, pp. 87-91.

Etsuyankpa, M. B. . et al. (2015) 'Assessment of the Effects of Microbial Fermentation on Selected AntiNutrients in the Products of Four Local Cassava Varieties from Niger State, Nigeria.', American Journal of Food Science and Technology, 3(3), pp. 89-96.

Ezekiel, O. O. . and Aworh, O. C. ; (2013) 'Solid-state fermentation of cassava peel with Trichoderma viride (ATCC 36316) for protein enrichment', International Journal of Biological, Biomolecular, Agricultural, Food and Biotechnological Engineering, 7(3), pp. 202-209.

Goni, I. ., Garcia-Alonso, A. . and Saura-Calixto, F.; (1997) 'A starch hydrolysis procedure to estimate glycemic indeks', Nutr Res, 17(3), pp. 427-437.

Hawashi, M. . et al. (2019) 'Optimization of solid state fermentation for cyanide content reduction in cassava leaves using Response Surface Methodology’, International Journal of Technology, 10(3), pp. 624 633.

Hidayat, B. . et al. (2019) 'The growth dynamics, chemical, amylographic profile and granular morphology changes on cassava pulp fermentation', Asian Journal Agric \& Biol, 7(4), pp. 617-623.

Hidayat, B. ., Hasanudin, U. ., Muslihudin, M. ., et al. (2020) 'Growth kinetics of Saccharomyces cerevisiae and tape yeast on the cassava pulp fermentation', in Journal Phys.

Hidayat, B. ., Hasanudin, U. ., Nurdjanah, S. ., et al. (2020) 'Optimasi Karakteristik Tepung Komposit Berbasis Tepung Onggok Fermentasi Menggunakan Metode Response Surface Methodology (RSM)', Jurnal Aplikasi Teknologi Pangan, 9(3), pp. 126-132.

Hidayat, B. ., Muslihudin, M. . and Akmal, S. (2018) 'Perubahan Karakteristik Fisikokimia Tepung Onggok Selama Proses Fermentasi Semi Padat Menggunakan Saccharomyces cerevisiae', Jurnal Penelitian Pertanian Terapan, 18(3), pp. 146-152.

Iwuoha, G. N. ., Ubeng, G. G. . and Onwuachu, U. I. ; (2017) 'Detoxification Effect of Fermentation on Cyanide Content of Cassava Tuber', Journal Appl. Sci. Environ. Manage, 17(4), pp. 567-570.

Kaewwongsa, W. . et al. (2010) 'Protein Enrichment of Cassava Pulp Fermentation by Saccharomyces cerevisiae.', Journal Anim Vet Adv, 10(18), pp. 2434-2440.

Lambri, M. . et al. (2013) 'Improved processing methods to reduce the total cyanide content of cassava roots from Burundi’, Journal Biotechnol, 12(19), pp. 2685-2691.

Murugan, K. ., Yashotha, Sekar, K. . and Al-Sohaibani, S. ; (2012) 'Detoxification of cyanides in cassava flour by linamarase of Bacillus subtilis KM05 isolated from cassava peel', Journal Biotechnol, 11(28), pp. 7232-7237.

Oboh, G. . and Akindahunsi, A. A. (2003) 'Biochemical changes in cassava products (flour \& gari) subjected to Saccharomyces cerevisiae solid media fermentation', Food Chem, 82, pp. 599-602.

Onyesom, I. ., Okoh, P. N. . and Okpokunu, O. V.; (2008) 'Levels of Cyanide in Cassava Fermented with Lemon Grass (Cymbopogon citratus) and the Organoleptic Assessment of its Food Products', World Appl. Sci. Journal, 4(6), pp. 860-863.

Soekarto, S. T. (1985) Penilaian Organoleptik untuk Industri Pangan dan Hasil Pertanian. Jakarta: Bhratara. 
Jurnal Penelitian Pertanian Terapan

Suroso, E. (2011) Model Proses Produksi Industri Tapioka Ramah Lingkungan Berbasis Produksi Bersih (Studi Kasus di Provinsi Lampung).

Ubalua, A. O. (2007) 'Cassava wastes: treatment options and value addition alternatives', Journal Biotechnol, 6(18), pp. 2065-2073. 